\title{
Performance and Degradation Evaluation of Five Different Commercial Lithium-Ion Cells
}

\author{
Kathryn A, Striebel and Joongpyo Shim \\ Environmental Energy Technologies Division \\ Lawrence Berkeley, National Laboratory \\ Berkeley, CA 94720
}

\begin{abstract}
The initial performance of five different types of Li-ion rechargeable batteries, from Quallion Corp, UltraLife Battery and Toshiba, was measured and compared. Cell characterization included variable-rate constant-current cycling, various USDOE pulsetest protocols and full-spectrum electrochemical impedance spectroscopy. Changes in impedance and capacity were monitored during electrochemical cycling under various conditions, including constant-current cycling over 100\% DOD at a range of temperature and pulse profile cycling over a very narrow range of DOD at room temperature. All cells were found to maintain more than $80 \%$ of their rated capacity for more than 400 constant current $100 \%$ DOD cycles. The power fade (or impedance rise) of the cells varied considerably. New methods for interpreting the pulse resistance data were evaluated for their usefulness in interpreting performance mechanism as a function of test protocol and cell design.
\end{abstract}




\section{Introduction}

The research and development of rechargeable batteries for the electric vehicle program at LBNL has been on going for more than 20 years. As part of a reorganized and more-focused effort, two specific chemistries within the realm of rechargeable lithium-ion cells are being evaluated: a high-power liquid cell with a cathode constructed from the layered oxide $\mathrm{LiNi}_{0.8} \mathrm{Co}_{0.15} \mathrm{Al}_{0.05} \mathrm{O}_{2}$ and a synthetic graphite anode, and a lowcost gel electrolyte system with a spinel or $\mathrm{LiFePO}_{4}$-type cathode, a natural graphite anode and gelled-polymer electrolyte [1]. The reasons for incorporating a gel electrolyte system are 1) stabilization of the liquid electrolyte, 2) creating a more-stable less-resistive interface between the separators and the electrodes that does not require external compression. Three possible approaches to a gel cell include a pure gel separator, such as with the Bellcore technology [2], a polymer-coated microporous separator (MPS) such as a PVdF-coated Celgard [3] and regular MPS, which is assembled as with a liquid electrolyte cell, and the monomer/electrolyte solution is added and the cell pack is cured in-situ [4]. The latter two approaches retain the safety and mechanical integrity features inherent in the use of an MPS.

Five different commercially available gel and liquid-electrolyte cells were studied to evaluate the status of the existing technology as well as for the development of the necessary test protocols for future research cells. The cells fell into two groups by electrolyte. Two liquid electrolyte cells were prepared by Quallion Corp., in two designs, a high-power cell, developed for the ATD program and a high-energy design, Quallion's product. The former contains a $\mathrm{LiNi}_{0.8} \mathrm{Co}_{0.15} \mathrm{Al}_{0.05} \mathrm{O}_{2}$ and the later and all the other cells contain $\mathrm{LiCoO}_{2}$ as the cathode-active material. The three gel cells evaluated come from three different manufacturers, Doo Youn, Toshiba and UltraLife. The Doo Youn and Toshiba cells also contain a microporous separator.

In this work, we compare and contract the initial performance of the commercially prepared cells and follow the capacity and power retention during 100\% DOD cycling at $\mathrm{C} / 2$ rate between voltage limits suggested by the manufacturers. In addition, the power fade for the ATD-type cell during constant-current 100\%DOD cycling and PNGV Power-Assist pulse cycling was compared at a comparable level of capacity throughput. . 


\section{Experimental}

Cells were tested using battery cycling hardware from Arbin Corp and Maccor. As-received cells were characterized initially with a $\mathrm{C} / 25$ test to assess the as-delivered SOC and the active material available in the capacity-limiting electrode, usually the cathode. In all cases, the rated capacity was taken from the manufacturers data. Following the $\mathrm{C} / 25$ test, a set of variable-rate cycles was carried out at constant current utilizing a $\mathrm{C} / 2$ taper charge and 3-5 cycles at each of 4 different discharge rates, C/5, C/2, C and 2C. These data are very useful for understanding of the expected cycling behavior and help determine the choice of maximum current pulses for the power test protocols.

Cell impedance as a function of state-of-charge (SOC) was measured for fresh cells and during cycling studies with three different methods: the USABC peak power test (USABCPT)[5], the PNGV Reference Performance Test (RPT) [6] and full-spectrum electrochemical impedance spectroscopy (EIS). Both the USABC-PT [5] and the RPT, including the hybrid pulse power characterization (HPPC) were implemented on the Maccor Battery Cycler. The differences between the two "DC" techniques will be discussed below. For some cells EIS data were recorded as a function of SOC with a Solartron 1260 FRA and a Solartron 1286 potentiostat using a perturbation of $\pm 10 \mathrm{mV}$ between $80 \mathrm{k}$ and $60 \mathrm{mHz}$ and controlled with CorreWare software from Scribner \& Associates. These data were analyzed with the ZPlot software package. Following this characterization protocol, cells were cycled over 100\% DOD with constant current of C/2 between manufacturers-suggested voltage limits with a taper charge to a minimum current of about $\mathrm{C} / 20$. Cycling was interrupted every 80 cycles for an additional impedance test. After about 400 cycles, or $60 \%$ loss in capacity, cycling was terminated and a final $\mathrm{C} / 25$ measurement was carried out ending with a discharge to the lower voltage limit. The power-Assist Lifecycle profile was implemented on the Maccor Battery cycler. 


\section{Results}

\section{The Cells}

A summary of the gross cell characteristics is given in Table 1. Where available, information was taken from cell specifications. However, some cells were disassembled and subjected to limited analyses.

\section{$\underline{\text { Doo Youn Cells }}$}

Ten Doo Youn SLPB640 cells contain $\mathrm{LiCoO}_{2}$ as the cathode active material and graphite in the anode. The cathode contains both amorphous carbon and graphite, as determined with Raman. The anode was analyzed with TEM and found to contain 2 types of graphitic particles: a spherical part reminiscent of MCMB and a flakier fraction. This cell was listed on the Doo Youn website as a polymer cell. The separator was a Celgard type separator, probably with a gel layer dispersed on it. The cell pack consisted of prismatic pieces wrapped in accordion fashion with the separator, including a few extra wraps on the outside of the pack. The pack is held in place with a piece of green tape. The pack consisted of 7 negatives and 6 positives, all coated on both sides of solid current collectors. On disassembly the separator was stuck slightly to the positive electrode, although it was very easily removed without the removal of any of the electrode surface.

\section{Toshiba Cell}

The LAB363456 cell from Toshiba is also composed of $\mathrm{LiCoO}_{2}$ and graphite. This cell is also listed as a "polymer" cell and also clearly contains an MPS. We believe it to be constructed with a thermally cross-linked gel containing gamma-butyrolactone $(\gamma \mathrm{BL})$.[7]. The active area was $260 \mathrm{~cm}^{2}$ and the cell was constructed from a single anode and cathode, wound together with the separator in a flat wound configuration. The anode was enclosed in the separator and the two layers stuck reasonably well on disassembly. However, the layers were separable without transfer of material. An uncoated portion of the cathode current collector comprised the outermost wound layer. 


\section{$\underline{\text { UltraLife Cells }}$}

Several UltraLife UBC443483 cells were purchased from UltraLife Battery Company, Newark, NY. These cells are constructed with $\mathrm{LiCoO}_{2}$, graphite and the Bellcore type electrolyte system [2], and represent the only cell in this study without an MPS. Seven bi-cells (dual-sided anode between two single-sided cathodes) make up the cell pack with the back-to-back expanded metal Al current collectors providing direct inplane connectivity. Many aspects of this cell have been reported [8]. The cells received contained a Raychem LR-380 PPTC (polymer positive thermal coefficient) device for safety shut down and for most studies this circuit was left intact. One cell characterized after removal of this circuit suggests that the impedance of this circuit is about $65 \mathrm{~m} \Omega$. 
Table 1. Cells Gross Details

\begin{tabular}{|l|l|l|l|l|l|}
\hline Manufacturer & $\begin{array}{l}\text { Doo } \\
\text { Youn }\end{array}$ & Toshiba & UltraLife & $\begin{array}{l}\text { Quallion } \\
\text { HP }\end{array}$ & $\begin{array}{l}\text { Quallion } \\
\text { HE }\end{array}$ \\
\hline Designation & SLPB640 & LAB363456 & UBC443483 & Q0120V & Q0100E \\
\hline Country & Korea & Japan & USA & USA & USA \\
\hline Interfacial area $\left(\mathrm{cm}^{2}\right)$ & 180 & 260 & 281 & 90.8 & 39.3 \\
\hline Winding type & accordion & flat wound & prismatic & $\begin{array}{l}\text { flat } \\
\text { wound }\end{array}$ & $\begin{array}{l}\text { flat } \\
\text { wound }\end{array}$ \\
\hline Rated Capacity $(\mathrm{mAh})$ & 640 & 575 & 725 & 100 & 100 \\
\hline C/25 Capacity $(\mathrm{mAh})$ & 680 & 634 & 773 & 114 & 150 \\
\hline Q_25/Q_rated & 1.06 & 1.10 & 1.07 & 1.14 & 1.5 \\
\hline $\begin{array}{l}\text { Capacity Density } \\
\text { mAh/cm } 2\end{array}$ & 3.8 & 2.4 & 2.6 & 1.1 & 3.8 \\
\hline $\begin{array}{l}\text { ASI at 50\% SOC }(\Omega- \\
\left.\mathrm{cm}^{2}\right)\end{array}$ & 44 & 60 & $93 *$ & 41 & 43 \\
\hline Voltage Range & $4.2-2.7$ & $4.2-3.0$ & $4.2-3.0$ & $4.1-3.0$ & $4.2-2.7$ \\
\hline
\end{tabular}

\section{Quallion Cells}

Two types of liquid-electrolyte cells were purchased from Quallion Corp, Sylmar, CA and tested for comparison with the polymer cells, high-power (Q0120V) cells and high-energy (Q0100E) cells. Both types are rated at $100 \mathrm{mAh}$ and consist of a single positive and negative electrodes wound and packed in a cathode-positive rigid can. The Q0120V have $84 \%$ active $\mathrm{LiNi}_{0.8} \mathrm{Co}_{0.15} \mathrm{Al}_{0.05} \mathrm{O}_{2}$ in the cathode along with graphite (4\% SFG-6) and carbon black (4\% Shawinigan black) for added conductivity. The anode contains 90\% Mag-10 synthetic graphite. The separator is Celgard 2500 and the electrolyte is $1.2 \mathrm{M} \mathrm{LiPF}_{6} / \mathrm{EC} / \mathrm{EMC}$. These cells are considered to be high-power because the electrode loading is low $\left(1.2 \mathrm{mAh} / \mathrm{cm}^{2}\right)$ and the interfacial area relatively large at $91 \mathrm{~cm}^{2}$. These are smaller versions of the 18650 Gen 2 cells under investigation by the ATD program [9].

The Q0100E cells contain a $\mathrm{LiCoO}_{2}$-based cathode, a graphite anode and $\mathrm{LiPF}_{6} /$ carbonate electrolyte with an MPS separator. These cells contain about the same capacity as the Q0120V cells packed into a lower area $\left(39 \mathrm{~cm}^{2}\right)$ typical of a high-energy versus high-power battery design. The loading was significantly higher for this highenergy design $\left(2.8 \mathrm{mAh}\right.$-active/ $\left.\mathrm{cm}^{2}\right)$ while as is evident from Table 1 , these cells contain a fairly large excess capacity. 


\section{Electrochemical Characterization}

Several electrochemical characterization tests were carried out to provide baseline information on the cells.. Low-rate cycling (C/25) between suggested voltage limits was carried out to determine the active capacity in the cell, often much different than the rated capacity. These data were converted to differential capacity plots $(\mathrm{dQ} / \mathrm{dV})$ to gain a fingerprint of the voltage profile for this capacity, similar to the information gained from a cyclic voltammogram. Changes in the $\mathrm{C} / 25$ capacity vs. the higher rate capacity are useful for distinguishing between capacity-fade mechanisms. Various impedance and variable rate cycling studies were carried out to characterize the power capability of the cells as a function of cycle-life. This type of characterization is often reported only for fresh cells, whereas the maintenance of power is as important as capacity for performance, especially in HEV and EV applications. In addition, impedance is a good tool for the diagnostic analysis of failure mechanisms in a battery. These characterization tools were used for fresh cells and then at intervals during cycle testing. C/25 Cycling

All cells were received at a state-of-charge (SOC) very close to 50\%, or around $3.7 \mathrm{~V}$. This is probably due to lower material degradation rates away from the voltage extremes. The $\mathrm{C} / 25$ capacities are summarized in Table 1 . All of the cells, except the Q0100E contained between 6 and 14\% excess capacity. The rated capacity is usually determined at a C-rate, as will be apparent in the next section. The differential capacity plots for the two Quallion (liquid-electrolyte) cell chemistries and the four $\mathrm{LiCoO}_{2}$ cells with various separator systems are compared in Figures 1A and B, respectively. To enable direct comparison between cells of different capacities, these data were normalized to a capacity of $100 \mathrm{mAh}$ by means of the rated capacity. In cells that contain a reference electrode or with a lithium anode, these data are fairly straightforward to interpret $[10,11]$. However, differences between what we know about the cells and changes with cycling may yield interesting information, even in the absence of a reference electrode. The traces in Fig. 1A show that the significantly lower voltage nature of the $\mathrm{LiNi}_{0.8} \mathrm{Co}_{0.15} \mathrm{Al}_{0.05} \mathrm{O}_{2}$ cell is characteristic of the oxide. Most of the cycling occurs around the Ni sites, at lower voltages than the $\mathrm{Co}^{3+/ 4+}$ process. The lack of clarity of the peaks is due to the smoothing of the energy levels by the presence o the dopant ions, also 
characteristic of the oxide, and possibly lower crystallinity. This has been examined in detail previously for the oxide with [12] and without Al [13]. The variation in shapes of these plots for the $\mathrm{LiCoO}_{2}$ cells in Fig. 1B is somewhat surprising. All traces contain multiple peaks. When $\mathrm{Li}_{\mathrm{X}} \mathrm{CoO}_{2}$ is measured against a $\mathrm{Li}$ anode, major peaks are expected at 3.94 and $3.87 \mathrm{~V}$ vs. $\mathrm{Li} / \mathrm{Li}^{+}$, for the anodic and the cathodic processes, respectively, with minor peaks at 4.08/4.02 and 4.20/4.12 [13]. These should correlate well with the more highly charged peaks, since the graphite anodes should be at a fairly constant voltage near $0.1 \mathrm{~V}$ vs. $\mathrm{Li} / \mathrm{Li}^{+}$. However, as the voltage of the anode starts to rise near the end-of discharge, the positions of these peaks will shift. The $\mathrm{Li}_{\mathrm{x}} \mathrm{CoO}_{2}$ cells in Fig.1 show significantly more peaks which can be attributed to different staging processes in the graphite anodes. Little more can be inferred without further information on the types of graphite. Accounting for the noise that is standard with this sort of differentiation calculation, there are 4 major processes apparent in all of these cells. The lowest voltage peak is probably due to the anode, and the second peak, which appears as $1-3$ different processes, is probably a splitting of the main $\mathrm{Li}_{\mathrm{x}} \mathrm{CoO}_{2}$ peak by the exertion of the anode. The sharpness of the peaks in Fig. 1 will also depend both on the crystallinity of the active materials as well as the conductivity of the different components. We have no information on the sources of oxide in these cells, however we can say that the relative sharpness in these plots does not correlate with the baseline cell impedances from Table 1. The highest-impedance cells from UltraLife show the most peak resolution. The effect of crystallinity is particularly obvious in Fig. 1B. The doping of the $\mathrm{LiNi}_{0.8} \mathrm{Co}_{0.15} \mathrm{Al}_{0.05} \mathrm{O}_{2}$ disrupts the crystallinity of the oxide resulting in smearing of plateaus in a titration curve or a widening of peaks in a $\mathrm{CV}$ or $\mathrm{dQ} / \mathrm{dV}$ plot, as mentioned above. For some cells this test was repeated periodically and at the end of cycling, to help ascertain the operative degradation mechanisms. Those results will be presented below.

\section{$\underline{\text { Variable-Rate Cycles }}$}

These data are shown in Figure 2, as the fraction of the rated capacity delivered as a function of discharge rate. It is clear for these 3 cells that the rated capacity is delivered at a C-rate for a fresh cell. One might be tempted to correlate cell impedance with the 
slope of this plot. However, as will be seen in the next section, the slopes of the plots in this figure correlate with the active material loading. UltraLife reports that $90 \%$ of capacity is deliverable at up to 5C[8]. Extrapolation of the data in Fig. 2 suggests that this capacity will only be available to about $2-3 \mathrm{C}$.

\section{Area Specific Impedance (ASI)}

Three different techniques were used to characterize cell impedance as a function of SOC: two DC methods, utilizing current pulses, and Electrochemical Impedance Spectroscopy (EIS) measurements over a wide frequency range. The DC impedance was measured at the beginning of life and during cycling with the two different profiles, shown in Figure 3. The USABC Peak Power Test [5] consists of a normal charge and then a series of 30s discharge pulses at the highest possible rate separated by base current discharges to $10 \%$ increments of the SOC. No open circuit periods are specified, so the discharge pulses are dynamic, dependent on the polarization from the previous measurement. The peak and base currents are chosen so that the cell does not reach the lower voltage limit at the $90 \%$ DOD pulse, and so the overall discharge rate is $\mathrm{C} / 3$. Resistance data are calculated from the values shown in the figure and data are reported as a percentage of the depth of discharge since there is no measure of OCV immediately before the pulse. The Hybrid Pulse Power Characterization (HPPC) profile specified by PNGV [6] is significantly more complicated with a 1-hour rest before each discharge pulse so the discharge portion requires at least 10 hours. It also involves pulses at 10\% increments in the SOC to give an area specific impedance (ASI) as a function of SOC. This profile involves a high current discharge pulse ( $18 \mathrm{~s}$ at $5 \mathrm{C}$ recommended for highpower cells) from an OC state, followed by a 30s OC period and a high current charge (regen, $10 \mathrm{~s}$ at $3.75 \mathrm{C}$ recommended) pulse. Because of the difference in pulse widths and the concentration polarization effects, the regen ASI will always be lower than the discharge ASI for a reversible system.

The initial ASI data measured for the 5 cells in this study are shown in Fig. 4. These are all made with the USABC pulse power test. These data are also compared at $50 \%$ SOC listed in Table 1. The UltraLife cell data were corrected for the $60 \mathrm{~m} \Omega$ supplied 
by the protective circuit. All of the cells show an increase in impedance with lithium content or \%DOD. These are 30s sustained discharge pulses and they are generally higher impedance than those measured with the 18s discharge specified by the HPPC.

The frequency dependent $(80 \mathrm{kHz}$ to $60 \mathrm{mHz})$ impedance for fully charged cells is shown in Fig. 5. Figure 5B shows the same data converted to ASI by the measured interfacial areas. Fig. 5B was added to aid in the comparison between EIS and DC results. It is clear that the magnitude of the ASI from the low frequency data is most similar to the DC data. Further comparisons will be made below. Recent reports suggest that the long inductive tail, often reported for very low-impedance cells, can be removed with proper 4 terminal cabling. With the Solartron equipment, we can vary the length of this tail with different cabling combinations, but it is always present.

\section{Analysis of Pulse Tests}

The HPPC test includes discharge pulses conducted from a fairly stable open circuit baseline (1 hour), it is tempting to mine these data further than suggested in the PNGV manual. An examination of the pulse shape for two different cells shows this simple analysis (Fig. 6). The data are recorded with 500ms seconds with the Maccor used in this study. The ohmic contribution to the $18 \mathrm{~s}$ discharge impedance can be estimated from the first measured voltage point after the pulse. This will include the electronic and ionic portions of the resistance. This separation of the pulse resistances will be examined mathematically with a model of the Li-ion cell and reported later [14]. One point to be examined is which component will be more sensitive to the buildup of surface films from unwanted side-reactions. The time spent at discharge leads to concentration polarizations due to slow diffusion in the open electrolyte or in any films formed on the electrodes (SEI layers or polymer deposits). The analysis is expected to yield additional insight into the impedance behavior of different cells as a function of cycling or calendar-life abuse.

This analysis is shown for three cell types in this study at the beginning of cell life in Fig. 6. These conversions are made in Figure 6B and 6C, respectively. The ohmic resistance in the UltraLife cell can be traced directly to the lower conductivity of the gel 
electrolyte separator compared to the liquid in the Celgard. The polarization contributions are similar for the three cells at high SOC. (The pores of the electrodes are filled with electrolyte of similar Li diffusivities?) The increase in polarization on discharge of the cell can be traced directly to the $\mathrm{Li}_{\mathrm{x}} \mathrm{CoO}_{2}$. This oxide converts from a metallic state to a p-type semi-conductor form at a value of $\mathrm{x}$ between 0.97 and 0.8 , which is well in this range [15]. This is not observed in the Q0100E cell, probably because of the large excess capacity of this cell. The conductivity transition point for the $\mathrm{Li}_{\mathrm{x}} \mathrm{CoO}_{2}$ is never achieved since the effective $\mathrm{x}$ value for the fully discharged (at the rated capacity) cell is 0.81 , much lower than the 0.97 calculated for the UltraLife. The resistance measurements in Fig. $6 \mathrm{~B}$ suggest that this transition is also not achieved in the $\mathrm{LiNi}_{0.8} \mathrm{Co}_{0.15} \mathrm{Al}_{0.05} \mathrm{O}_{2}$ in the Q0120V cell however, similar conductivity data are not available for this material.

In general, only one type of pulse test was used on a cell. However, a direct comparison for a Q0120V cell later in life is shown in Fig. 7. ASI measured at two times in the HPPC data are compared with the dynamic 30s pulse data from the USABC profile. It is clear that time is the primary factor here. The inset shows the linear correlation of these resistances measured at 20\%DOD. The extrapolation to zero time should give the purely ohmic resistance for this measurement. This value from the inset data is $36 \Omega-\mathrm{cm}^{2}$. The purely ohmic resistance estimated from the $18 \mathrm{~s}$ HPPC pulse was $30 \Omega-\mathrm{cm}^{2}$ at the same SOC. The agreement here is pretty good. The ASI's measured with the HPPC regen pulses are on a different line. This is due to the fact that the starting point is not a rest potential, but a discharge pulse. The salt concentration in the pores will be higher from the previous discharge, so the extrapolated regen resistance is expected to be much lower, due to increased ionic conductivity in pores of the electrodes.

\section{C/2 Cycling}

A primary purpose of this work was develop a test protocol including electrochemical characterization, cycling and diagnostics to gain an understanding of the capacity and power fade characteristics of test cells made from candidate materials for an EV application. The primary aging tool therefore was $\mathrm{C} / 2$ cycling over the full capacity 
of the cell (100\% DOD). For some cells, this test was carried out at lower and higher than ambient temperature, namely 0 and $60^{\circ} \mathrm{C}$.

A summary of the discharge capacity performance of the five cells cycled at room temperature is shown in Figure 8. All of these cells cycle extremely well for 400 cycles at room temperature. Fade rates are in the range of .005 to $0.06 \% / c y c l e$, or maintenance of $76-98 \%$ of the rated discharge capacity after 400 cycles. The shift in capacity for the Toshiba cell was due to a change in the taper-charge cutoff criterion. These data and others are summarized in Table 2. The columbic and energy ratios (efficiencies) for these cycling data, are shown in Figures 9 A and B, respectively. All of the cells showed very close to $100 \%$ coulombic efficiency, while the energy ratios mimic the trends in the impedance.

\section{ASI Rise}

Cycling was interrupted approximately every 80 cycles for a measurement of the ASI. For the Doo Youn, Q0120V and the Toshiba cells, these power tests were done with the USABC profile. The HPPC profile was used for the UltraLife and Q0100E cells. ASI is shown as a function of cycle number in Fig. 10 for all of the cells. These data were obtained by interpolating the ASI for a mid-SOC, at 3.9V. This corresponds to between 18 and $36 \%$ SOC for all of the cells. The profiles and the average capacity and power fade rates calculated form these data are listed in Table 2. The Doo Youn cells and the liquid electrolyte cells tended to show monotonic increases in impedance with continued cycling. However, the UltraLife and the Toshiba cells tended to show constant ASI after an initial break-in period. This could be due to the stability in the interfaces afforded by the polymer-containing separators.

The HPPC data for the UltraLife and Q0100E cells were analyzed further as suggested above. Fig. 11 shows the polarization and ohmic resistances as a function of cycle number at an OCV of about 3.9V. Both liquid and gel electrolyte cells show a stabilization of the ohmic portion of the impedance while the liquid-electrolyte cell (Q0100E) shows a steadily increasing polarization impedance. The relations between 
these observations and the possible scenarios for performance degradation will be discussed below.

Table 2. Summary of performance during 100\% DOD Cycling

\begin{tabular}{|c|c|c|c|c|c|}
\hline Manufacturer & $\begin{array}{l}\text { Doo } \\
\text { Youn }\end{array}$ & Toshiba & UltraLife & $\begin{array}{c}\text { Quallion } \\
\text { HP }\end{array}$ & $\begin{array}{l}\text { Quallion } \\
\text { HE }\end{array}$ \\
\hline Model \# & SLPB640 & LAB363456 & UBC443483 & Q0120V & Q0100E \\
\hline Rated Capacity, mAh & 640 & 575 & 725 & 100 & 100 \\
\hline C/25 Capacity, mAh & 680 & 634 & 773 & 114 & 160 \\
\hline $\begin{array}{l}\text { Capacity Density, } \\
\mathrm{mAh} / \mathrm{cm}^{2}\end{array}$ & 3.8 & 2.4 & 2.6 & 1.1 & 4.1 \\
\hline $\begin{array}{l}\text { Avg. C/2 Cap. Loss, } \\
\% / \text { cycle (\# Cycles) }\end{array}$ & $\begin{array}{l}0.032 \\
(400)\end{array}$ & $\begin{array}{l}0.005 \\
(320)\end{array}$ & $\begin{array}{l}0.029 \\
(371)\end{array}$ & $\begin{array}{l}0.035 \\
(400)\end{array}$ & $\begin{array}{l}0.060 \\
(320)\end{array}$ \\
\hline $\begin{array}{l}\text { Avg. C/25 Cap. Loss, } \\
\% / c y c l e ~(\# \text { Cycles) }\end{array}$ & $\begin{array}{l}0.095 \\
(432)\end{array}$ & NA & $\begin{array}{l}0.036 \\
(371)\end{array}$ & $\begin{array}{l}0.004 \\
(400)\end{array}$ & $\begin{array}{l}0.094 \\
(320)\end{array}$ \\
\hline $\begin{array}{l}\text { Profile for ASI } \\
\text { Testing }\end{array}$ & USABC & USABC & HPPC & USABC & HPPC \\
\hline $\begin{array}{l}\text { Fresh Cell ASI at } \\
3.9 \mathrm{~V}, \Omega-\mathrm{cm}^{2}\end{array}$ & 42 & 72 & $88 *$ & 47 & 39 \\
\hline SOC at $3.9 \mathrm{~V}$ & 36 & 25 & 26 & 18 & 33 \\
\hline $\begin{array}{l}\text { Avg. ASI Rise, } \\
\% / \text { cycle (\# Cycles) }\end{array}$ & $\begin{array}{c}0.26 \\
(400)\end{array}$ & $\begin{array}{c}0 \\
(320)\end{array}$ & $\begin{array}{c}0.08 \\
(320)\end{array}$ & $\begin{array}{c}0.08 \\
(400)\end{array}$ & $\begin{array}{c}0.21 \\
(320)\end{array}$ \\
\hline
\end{tabular}

* Corrected for ohmic resistance of protective circuit 


\section{$\mathrm{LiCoO}_{2} /$ Graphite Cells at Variable Temperature}

Ten Doo Youn cells were tested in this project. The behavior of the room temperature-cycled cell has already been covered. Cycling behavior for all of the DY cells at 0,25 and $60 \mathrm{C}$ is shown in Fig. 12 . The first cell tested at $60^{\circ} \mathrm{C}$ blew up like a balloon within the first 50 cycles. The capacity dropped off very quickly due to a loss of contact between the layers. The second $60^{\circ}$ cell was constrained between Lucite plates and was able to cycle more than 200 times. There was some gas build-up in the headspace above the compression plates but it did not vent. These cells are rated as stable to $60^{\circ} \mathrm{C}$. However, this is probably for intermittent exposure only. The $0^{\circ} \mathrm{C}$ cells showed lower capacity and what appeared like a high rate of fade during cycling at $0^{\circ} \mathrm{C}$. However, this capacity was recovered when the temperature was raised to $25^{\circ} \mathrm{C}$ for a few cycles, and these cycles fell exactly on curve for the room temperature cells.

The dependence of the coulombic and energy efficiency of the Doo Youn cell for different temperature cycling is shown in Fig. 12B and C, respectively. The coulombic efficiency is close to $100 \%$ for 0 and $25^{\circ} \mathrm{C}$ and slightly lower for the $60^{\circ} \mathrm{C}$ cell. This is an indication of side-reactions going on in the cell. The coulombic efficiency measured for a $\mathrm{LiNi}_{0.8} \mathrm{Co}_{0.15} \mathrm{Al}_{0.05} \mathrm{O}_{2}$-containing pouch cell at $60^{\circ} \mathrm{C}[16]$ was essentially the same as that for the room temperature comparison. This suggests that the $\mathrm{LiNi}_{0.8} \mathrm{Co}_{0.15} \mathrm{Al}_{0.05} \mathrm{O}_{2}$ is less sensitive to side-reactions. This is probably a direct result of the lower voltages in the $\mathrm{Ni}$ based oxide $\left(\mathrm{LiNi}_{0.8} \mathrm{Co}_{0.2} \mathrm{O}_{2}\right.$ cells are routinely charged only to $4.1 \mathrm{~V}$, as opposed to the 4.2 upper limit for the $\mathrm{LiCoO}_{2}$ cell) and consequently lower tendency for oxidation processes at the higher temperatures. The energy efficiency for both 60 and $0^{\circ} \mathrm{C}$ is lower than that for the room temperature cells. Further studies of the dependence of these efficiencies on temperature will be added to the extended protocol testing of laboratory cells.

The ASI changes with cycling for these variable temperature experiments are shown in Fig. 13. The 25 and $60^{\circ} \mathrm{C}$ cells showed a monotonic increase in cell impedance with cycling. The behavior of the $0^{\circ} \mathrm{C}$ cell was more complex. A significant rise in impedance is observed on cooling the cell by only $25^{\circ} \mathrm{C}$. However, it appears that the 
degradation processes that lead to impedance rise are slowed at the lower temperature. The impedance still rises with cycling but at a lower rate than would've occurred at room temperature. This is behavior is clear from the first cell cycled at $0^{\circ} \mathrm{C}$ and somewhat obscured by the second such cell.

\section{Constant-Current vs. Power-Assist Pulse Cycling}

The Quallion Q0120V cell in the smaller version of the 18650, so-called Gen 2, cell constructed for the HEV testing in the ATD program, as mentioned about. In an $\mathrm{HEV}$, the cells will not be subjected to the stress of 100\% DOD constant current cycling. However, pulse testing could lead to power fade mechanisms, involved with the rapid volume changes occurring during the high-current pulses, or large polarization in the internal parts of the cell. To examine the effect of this pulse testing, in direct comparison with constant current testing, two Q0120V of similar initial capacity were tested with the two protocols and compared at approximately the same total Ah throughput. The PowerAssist profile, shown in Fig.14 is a controlled power profile so the cycle-capacity will be a function of the cell impedance. For the cell tested, about 40000 cycles corresponded to approximately $450100 \%$ DOD cycles on a $100 \mathrm{mAh}$ cell.

The $\mathrm{C} / 1$ capacity was calculated at a few intervals during the lifecycle testing as part of the reference performance test (RPT) /HPPC test. Fig. 15 shows that both capacity and power fade rates as a function of equivalent cycle are similar for these cells. After cycle testing, the $\mathrm{C} / 25$ characterization test was repeated. The differential capacity plots for the two cells after cycling under different conditions are compared (not shown). The shape change of these curves is somewhat different. The pulse-cycled cell shows more smearing of the voltage profile. This could be a clue to sources of power fade in this highly examined cell chemistry.

\section{Mechanisms for Capacity/Power Fade}

There are several sources for capacity and power fade in a lithium-ion cell. Fading of the discharge capacity during cycling can be caused by deactivation of the active 
material or simply by increased impedance causing premature voltage cut-off of the charge or discharge. It is sometimes possible to distinguish between these mechanisms by comparison of high and low-rate capacities. The Q0120V cell, cycled at room temperature, showed capacity fade attributable primarily to increased impedance, as can be ascertained by the significantly larger rate of fade on the $\mathrm{C} / 2$ when compared with the $\mathrm{C} / 25$ losses. The other cells, for which this data is available, showed comparable or larger losses for the $\mathrm{C} / 25$ capacity. In these cases, capacity fade must be caused in part by a loss in active material, due to structural rearrangement, electrical isolation of portions of the electrode, or loss of lithium inventory in the cell. These mechanisms can be separate or inter-related.

\section{$\underline{\mathrm{dQ} / \mathrm{dV} \text { vs Cycling }}$}

Some insight can be gained from the comparison of the $\mathrm{C} / 25$ cycles, in the form of $\mathrm{dQ} / \mathrm{dV}$ plots, as shown in Figure 16. The blunting of the $\mathrm{Li}_{\mathrm{x}} \mathrm{CoO}_{2}$ peaks could be due to a general loss of crystallinity, as discussed above, or possibly from a loss of electronic conductivity within the cathode. The movement of peaks along the potential scale might suggest phase separation in the active materials or significant changes in cell impedance. The slight changes in this curve for the $\mathrm{LiNi}_{0.8} \mathrm{Co}_{0.15} \mathrm{Al}_{0.05} \mathrm{O}_{2}$ cell (Fig. 17C) is striking. This may be a general advantage to starting with the lower crystallinity material. The moderate changes in dQ/dV shown in Figs. 16 can be contrasted with those in Figure 17 for the Doo Youn cell cycled at $60^{\circ} \mathrm{C}$, where, severe loss of active material capacity has been observed. Similar losses were observed in a $\mathrm{LiNi}_{0.8} \mathrm{Co}_{0.15} \mathrm{Al}_{0.05} \mathrm{O}_{2}$ cell cycled at $60^{\circ} \mathrm{C}[16]$. At the high temperatures, both the anode and cathode showed serious degradation, although the activity decline was blamed primarily on the lithium inventory loss though continual formation and destruction of the SEI layer on the anode. Such problems on the SEI are predicted from the measured stabilities of the carbonate solvents on the anode [17]. They are all designed for high-voltage stability but are known to be quite unstable on lithium metal.

\section{Post-Test Diagnostics}

Distinguishing between degradation mechanisms is difficult solely based on electrochemical diagnostics, though hints can be gained from changes in $\mathrm{dQ} / \mathrm{dV}$ plots. In 
previous work with the ATD program, more insight was achieved with the application of a myriad of ex-situ diagnostics of various cell components, after disassembly [18]. This extensive analysis was beyond the scope of this work with so many different cells.

In the cells examined by XRD, the overriding conclusions were that no degradation in the crystal structure of the positive active materials was observed. However, the SOC shown by the XRD does not agree with that from the potential to which the cell was cycled. This is consistent with a consumption of lithium inventory in the cell and a failure of the cell to be fully discharged. Raman examination of the cathode material from the Doo Youn cells is consistent regarding the SOC of the material. The surface of cycled $\mathrm{LiCoO}_{2}$ cathodes in fully discharged state consists of particles at various state of charge. However, evidence of surface morphology changes, crystal disorder, new oxide phases formation in cycled cells were found with this significantly more surface-sensitive technique. Due to lack of resources the full spectrum of diagnostics was reserved for research cells.

\section{Conclusions}

All of the cells tested show excellent maintenance of capacity through full depth of discharge cycling. However, the all show a significant increase in cell impedance which will result in the loss of power through out the life of the cell. Several electrochemical analysis techniques were employed to elucidate the reasons for this impedance rise. However, this will not even be an easy path to follow, even with extensive diagnostic analysis of of the cell components.

\section{Acknowledgement}

We gratefully acknowledge the supply of electrodes and cells from Quallion Corp., Ultralife and Karim Zaghib of HydroQuebec. This research was funded by the Assistant Secretary for Energy Efficiency and Renewable Energy, Office of Advanced Automotive Technologies, U. S. Department of Energy, under contract number DE- AC0376SF00098. . 


\section{References}

1. http://eetd.lbl.gov/BERC/BATT/BATT.html

2. A.S. Gozdz, J.-M. Tarascon and P.C. Warren, U.S. Patent No. 5,460,904.

3. A. Godz, I. Plitz, A. DuPasquuier and T. Zheng, Rechargeable Lithium Batteries, K. M. Abraham, E. S. Takeuchi, M. Doyle, PV 2000-21, Phoenix, Arizona, Fall 2000, p. 336.

4. A. Vallee, M. Armand, Y. Choquette, A. Belanger, M. Gautier, M. Perrier, K. Zaghib, E. Potvin, and S. Besner, US Patent No. 6,280,882, Aug. 2001.

5. USABC Electric Vehicle Battery Test Procedures Manual, rev. 2, DOE/ID-10479, Rev. 2, Jan. 1996.

6. PNGV Battery Test Manual, DOE/ID-10597, Revision 3, Feb. 2001.

7. M. Fujiwara, M. Sekino, K. Koiwa, A. Satoh, N. Takama and H. Hasebe, Abtract \#193, 198 ${ }^{\text {th }}$ Meeting of the Electrochem. Soc., Phoenix, AZ, Fall 2000.

8. E. Cuellar, M. E. Manna, R. D. Wise, A.B. Gavrilov, M.J. Bastian, R.M. Brey and J. DeMatteis, J. Power Sources, 96 (2001) 184.

9. Raymond A. Sutula et al., "FY 2000 Progress Report for the Advanced Technology Development Program," U.S. DOE, OAAT, December 2000.

10. J. Shim, K. A. Striebel, "Summary of Electrochemical Evaluations of Pouch Cells Prepared from the ATD Generation II Chemistry", to be submitted.

11. J. Barker, Electrochim. Acta 40, (1995) p. 1603.

12. C.G. Motloch and T. C. Murphy, "Overview of PNGV Battery Development and Test Programs", Adv. Auto. Batt. Conf., Las Vegas, NV, Feb. 2002.

13. J. Barker, J., R. Pynenburg, R. Koksbang and M.Y. Saidi, Electrochim. Acta 41, 2481 (1996).

14. K. A. Striebel and K. Thomas, "Mathematical analysis of Pulse data from Li-ion cells", to be submitted.

15. J. Molenda, A. Stoklose and T. Bak, Solid State Ionics, 36, 53 (1989).

16. J. Shim, R. Kostecki, T.J. Richardson, X. Song and K. A. Striebel, J. Power Sources, submitted, June 2002. 
17. X. Zhang, R. Kostecki, T. J. Richardson, J. K. Pugh and P.N. Ross, Jr., J. Electrochem. Soc. 148, A1341 (2001).

18. X. Zhang, P.N. Ross, Jr., R. Kostecki, F. Kong, S. Sloop, J.B. Kerr, K. Striebel, E.J. Cairns, and F. McLarnon, J. Electrochem. Soc. 148, A463 (2001). 

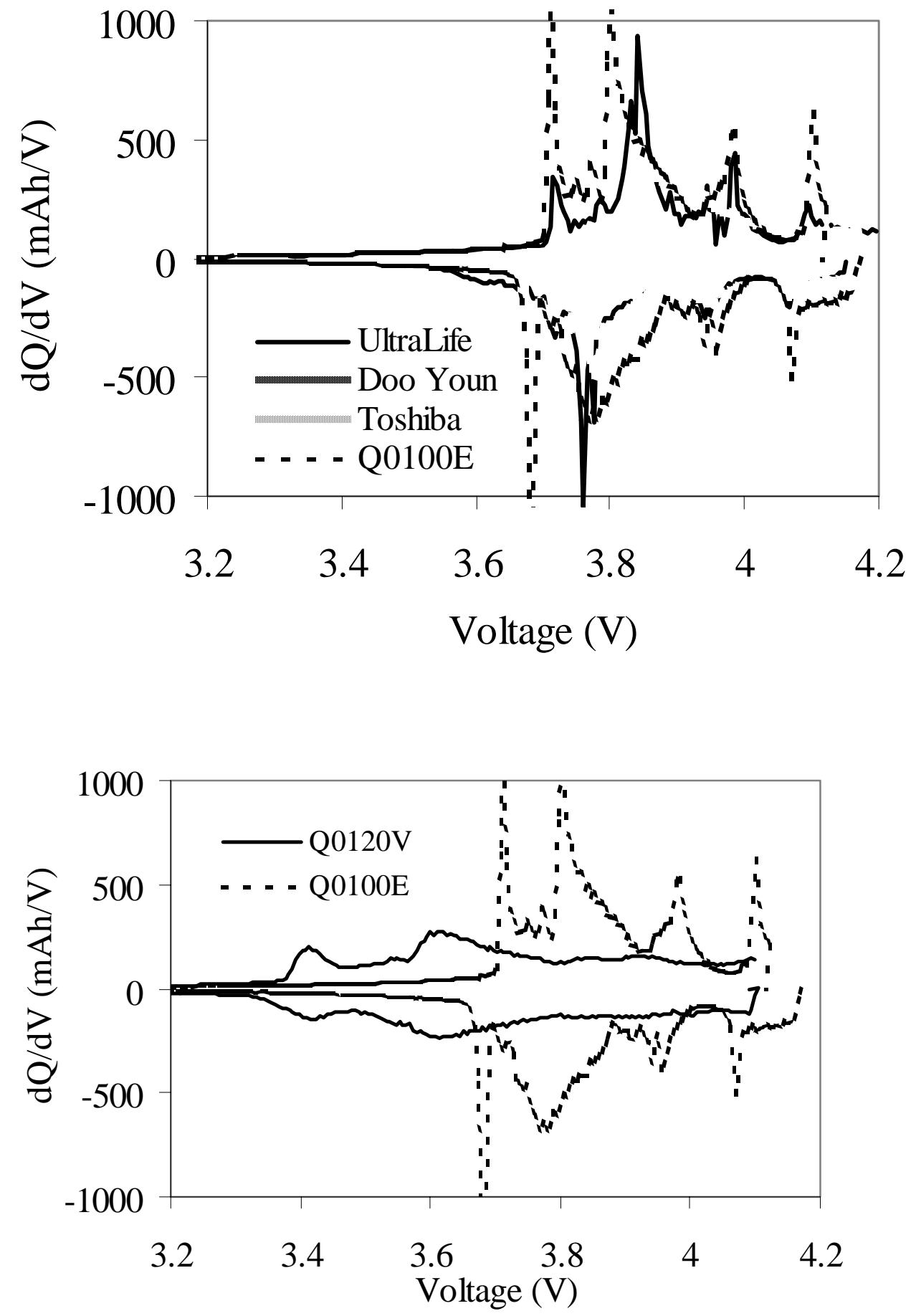

Figure 1. Differential Capacity Plots for 5 lithium-ion cells, normalized to a total capacity of $100 \mathrm{mAh}$. A: $\mathrm{Li}_{\mathrm{x}} \mathrm{CoO}_{2}$ / graphite cells, B: Quallion liquid electrolyte cells. 


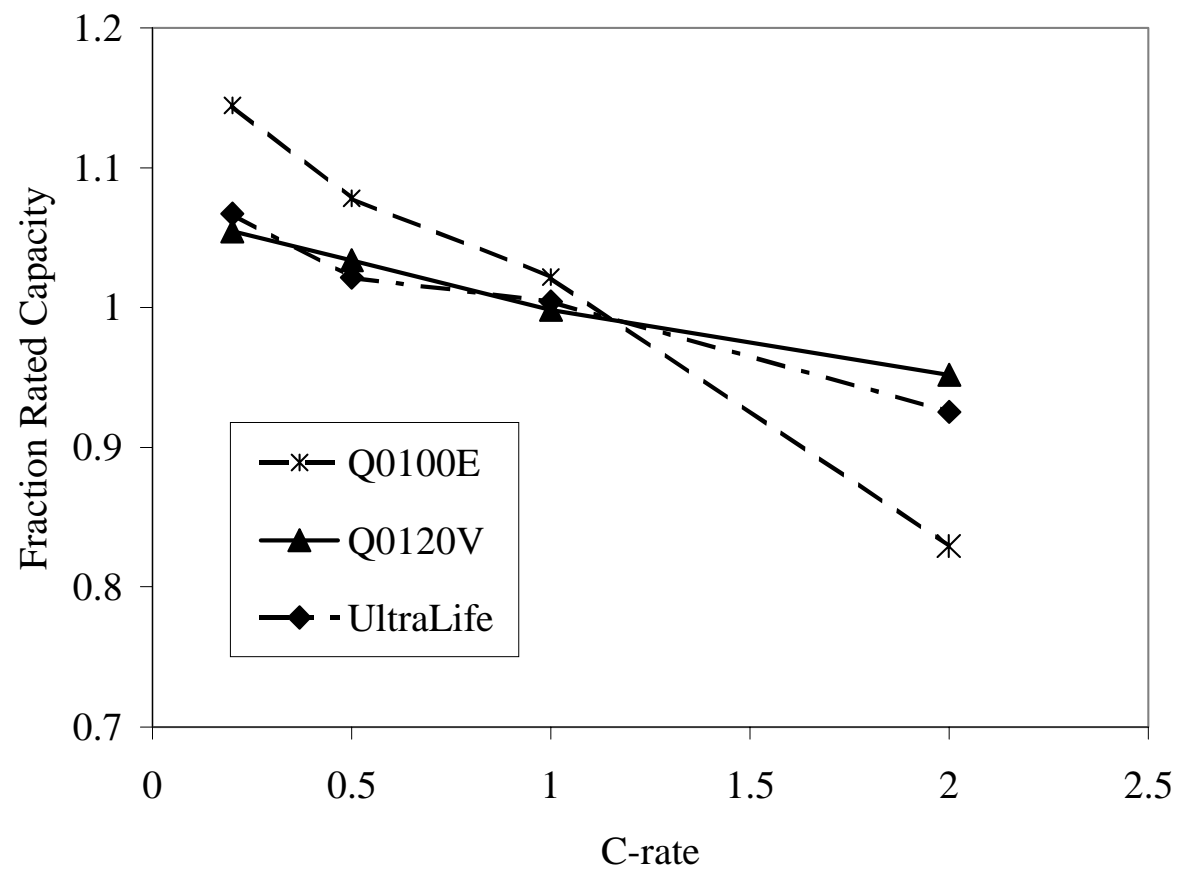

Figure 2. Variable rate discharge data for three cells. Cells were all taper-charged at C/2. Discharge capacity was normalized to the cell rated capacity. 

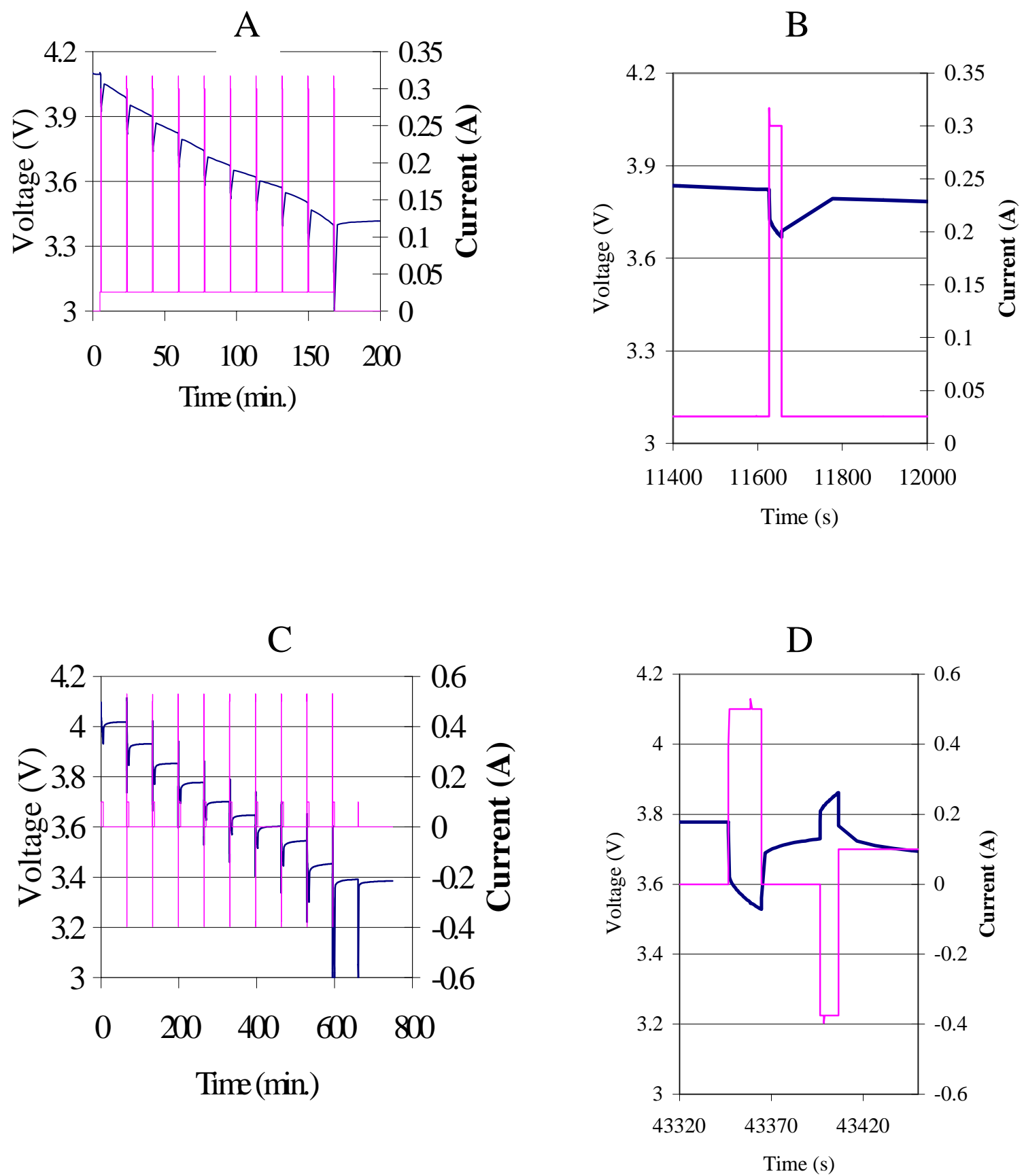

Figure 3. Sample voltage profiles for a cell subjected to the A: USABC pulse power capability test, C: the PNGV hybrid pulse power characterization (HPPC) profile, B and D: blow-up of a single pulse-set for A and C, respectively. 


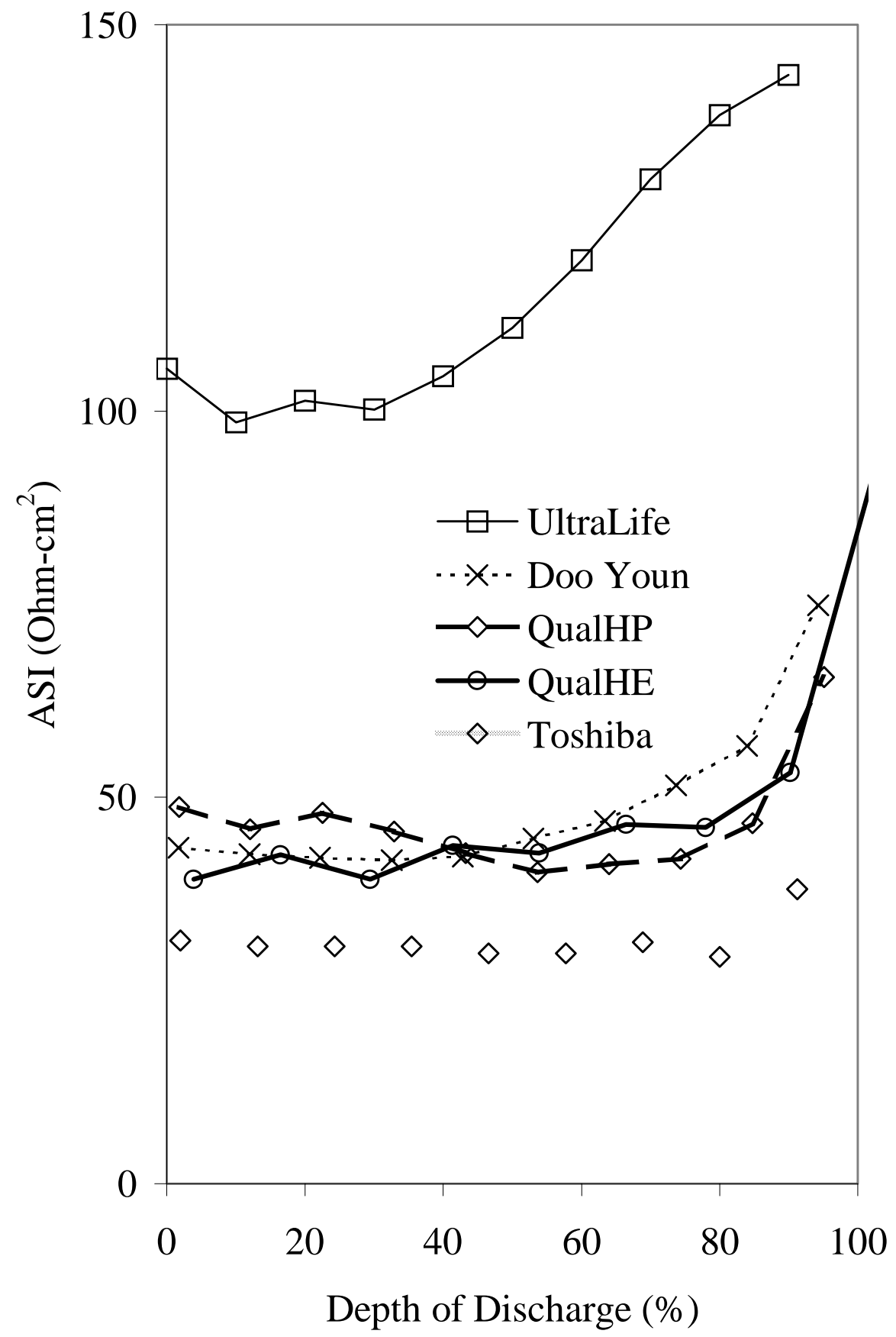

Figure 4. ASI measurements on fresh cells with the USABC pulse power profile. The UltraLife cell data have been corrected for the impedance of the Raychem LR-380 PPTC circuit. 


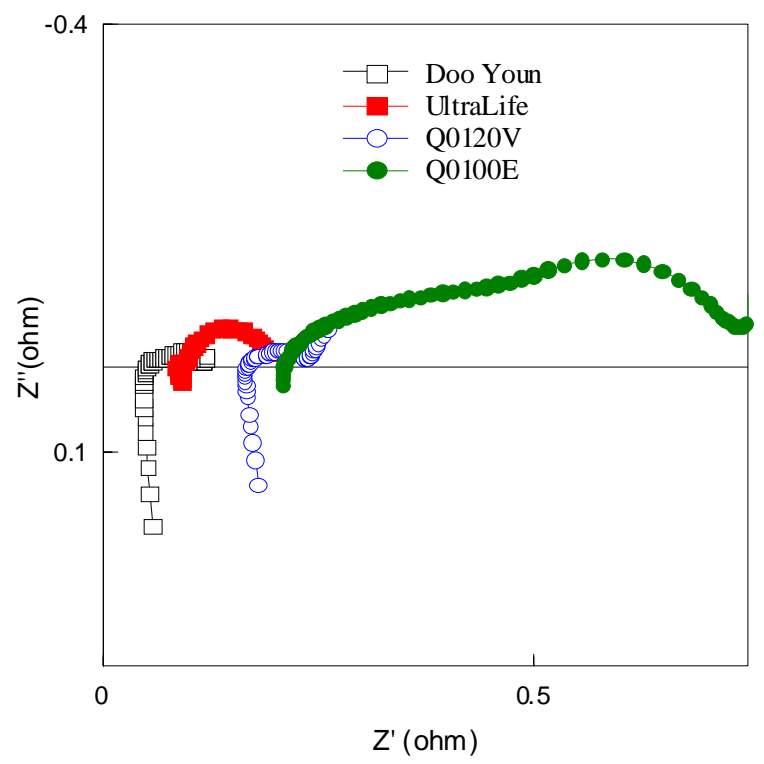

A

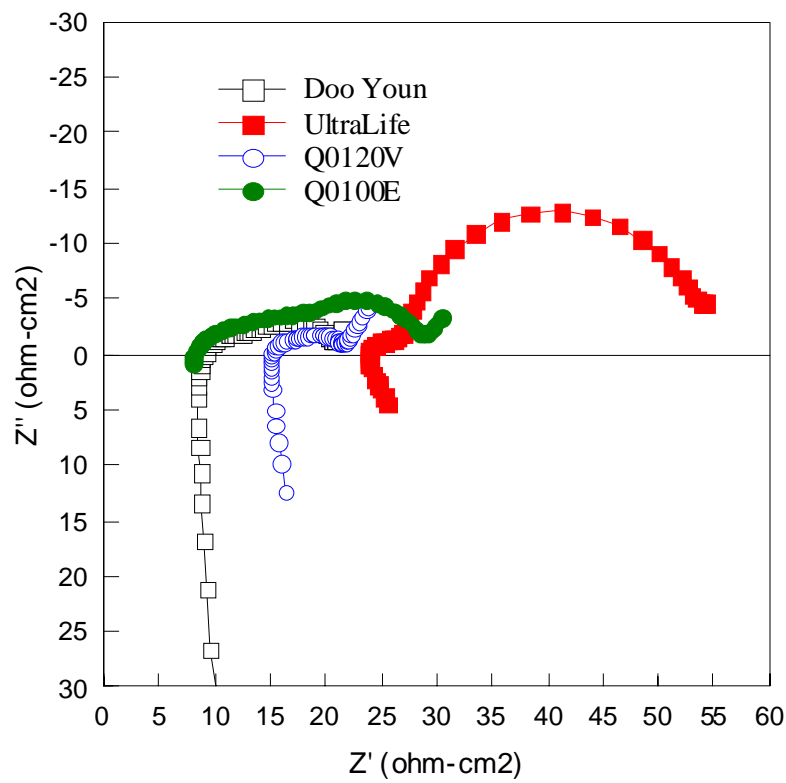

B

Fig. 5 EIS data from fully charged cells. A: Raw data, B: Corrected to ASI by interfacial active area. 

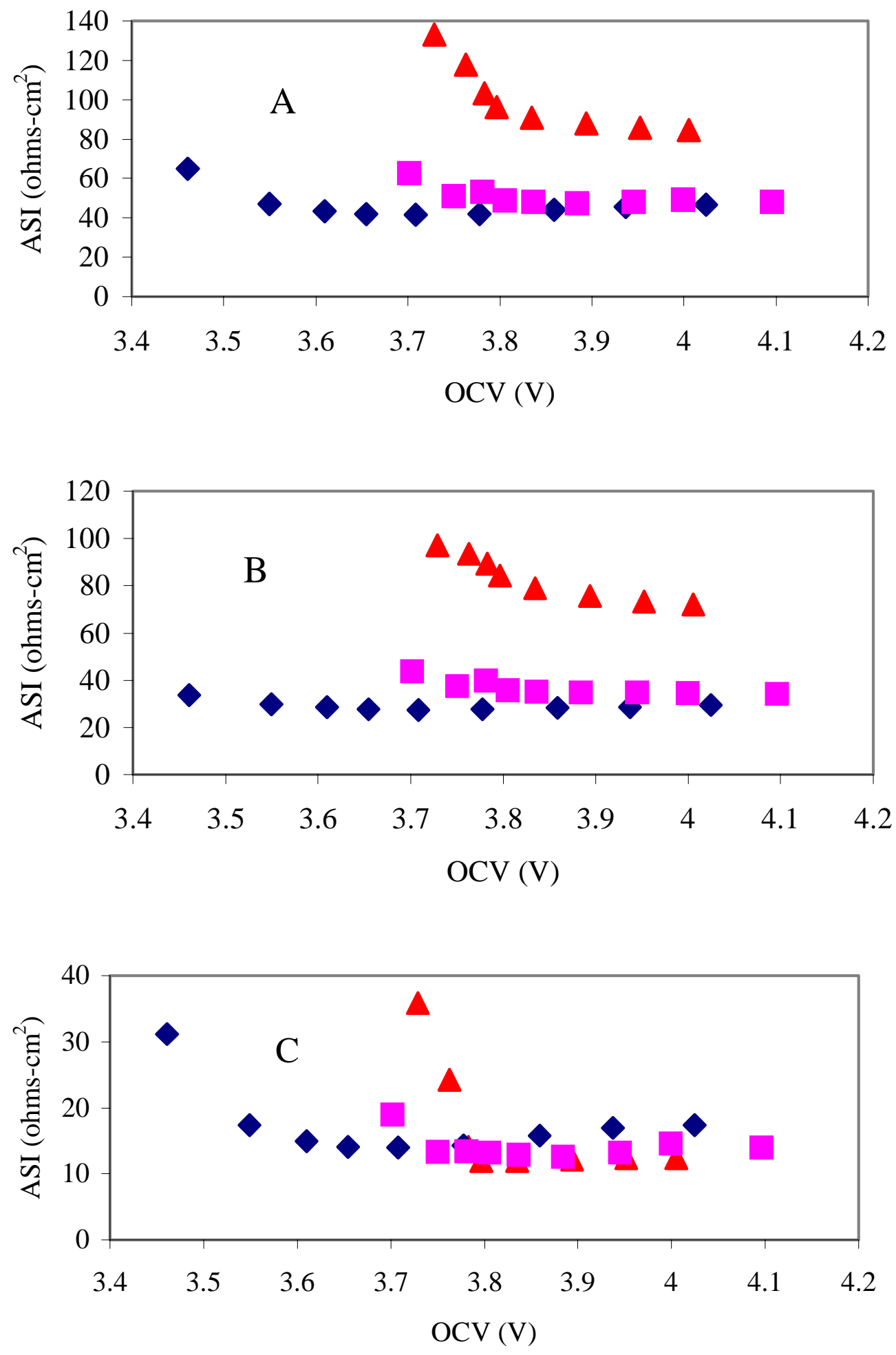

Figure 6. ASI calculated from the 18s discharge pulse of the HPPC profile for three fresh cells. Total ASI (A) separated in Ohmic portion (B) polarization ASI (C) according to technique discussed in the text. 
A
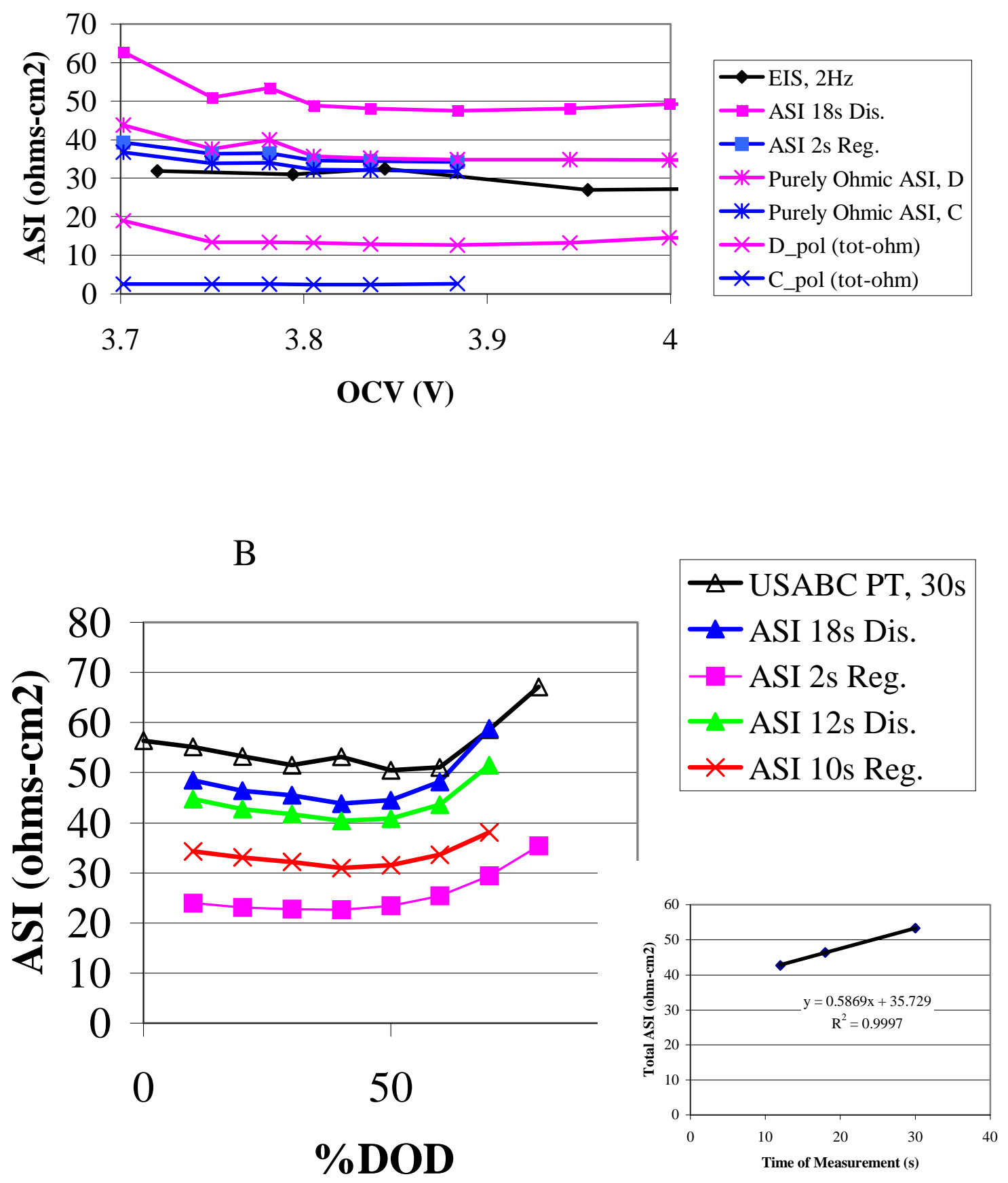

Figure 7. Comparison between ASI measured with different techniques, A: EIS and HPPC for Q0100E cell and B: HPPC and USABCPT results for Q0120V cell. 


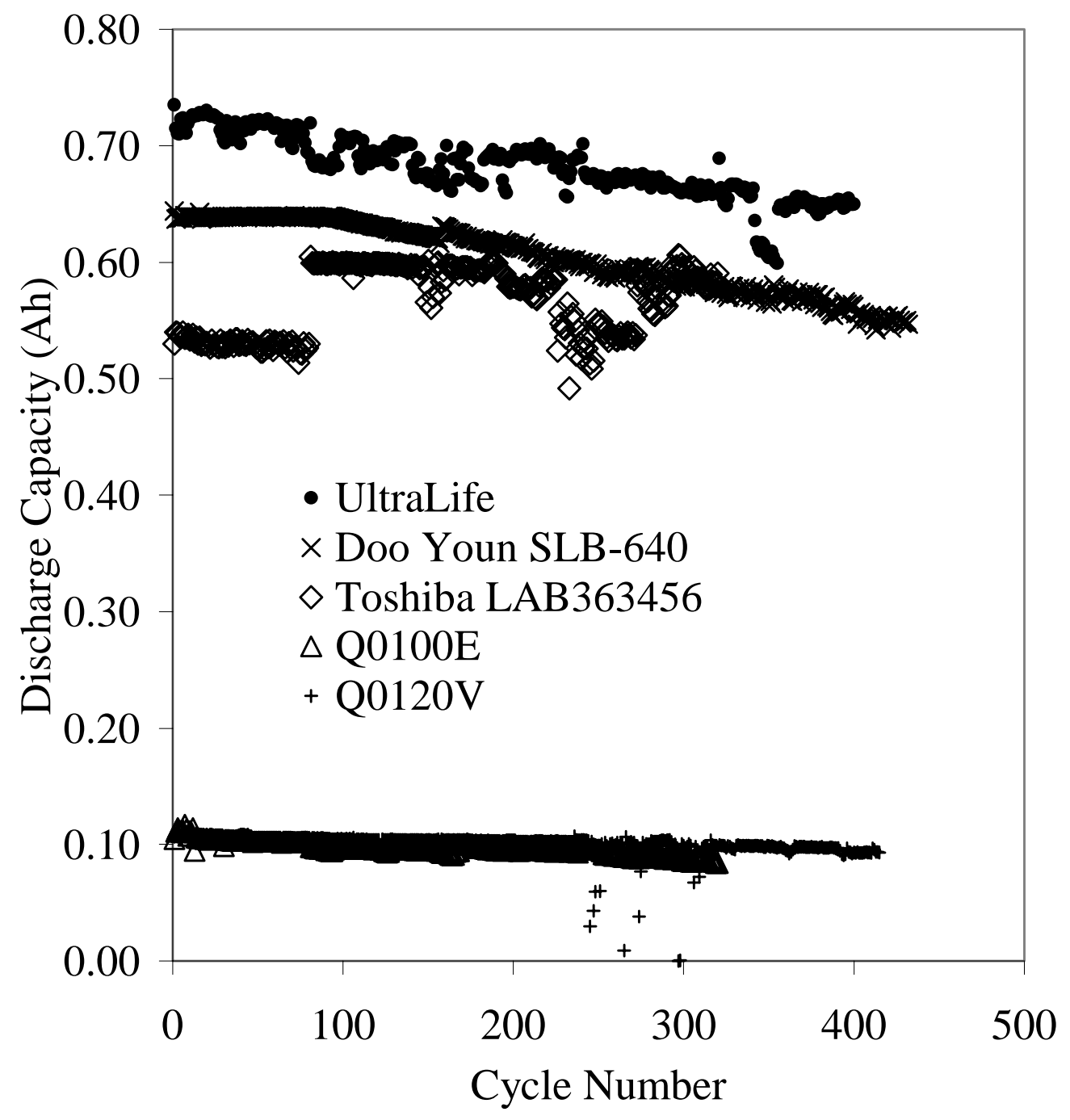

Figure 8. Comparison orf the discharge capacity during C/2, 100\% DOD cycling of five lithium-ion cells. 

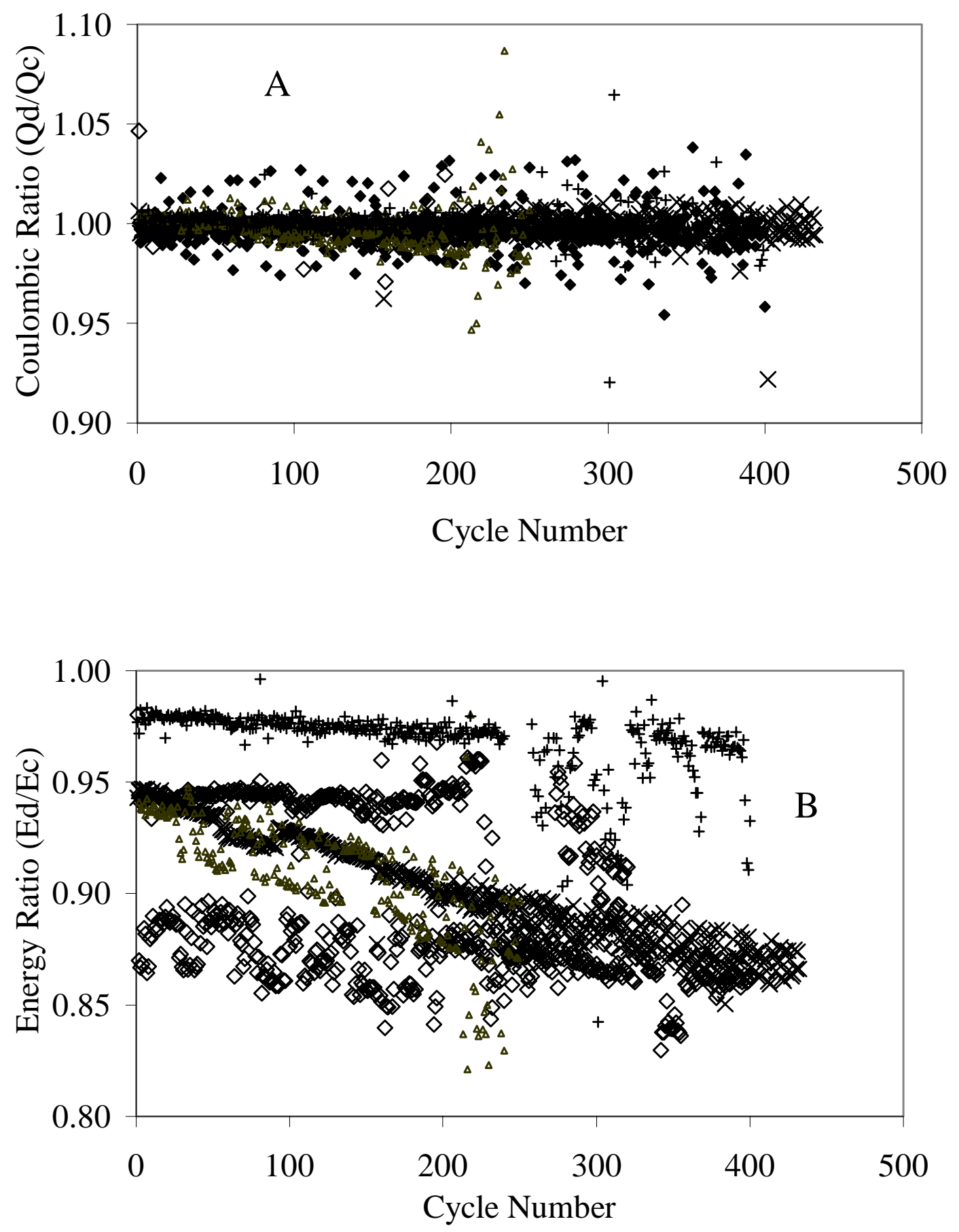

Figure 9. Coulombic (A) and energy efficiencies (B) for five Li-ion cells. See cycling data shown in Figure 8 for symbols.. 


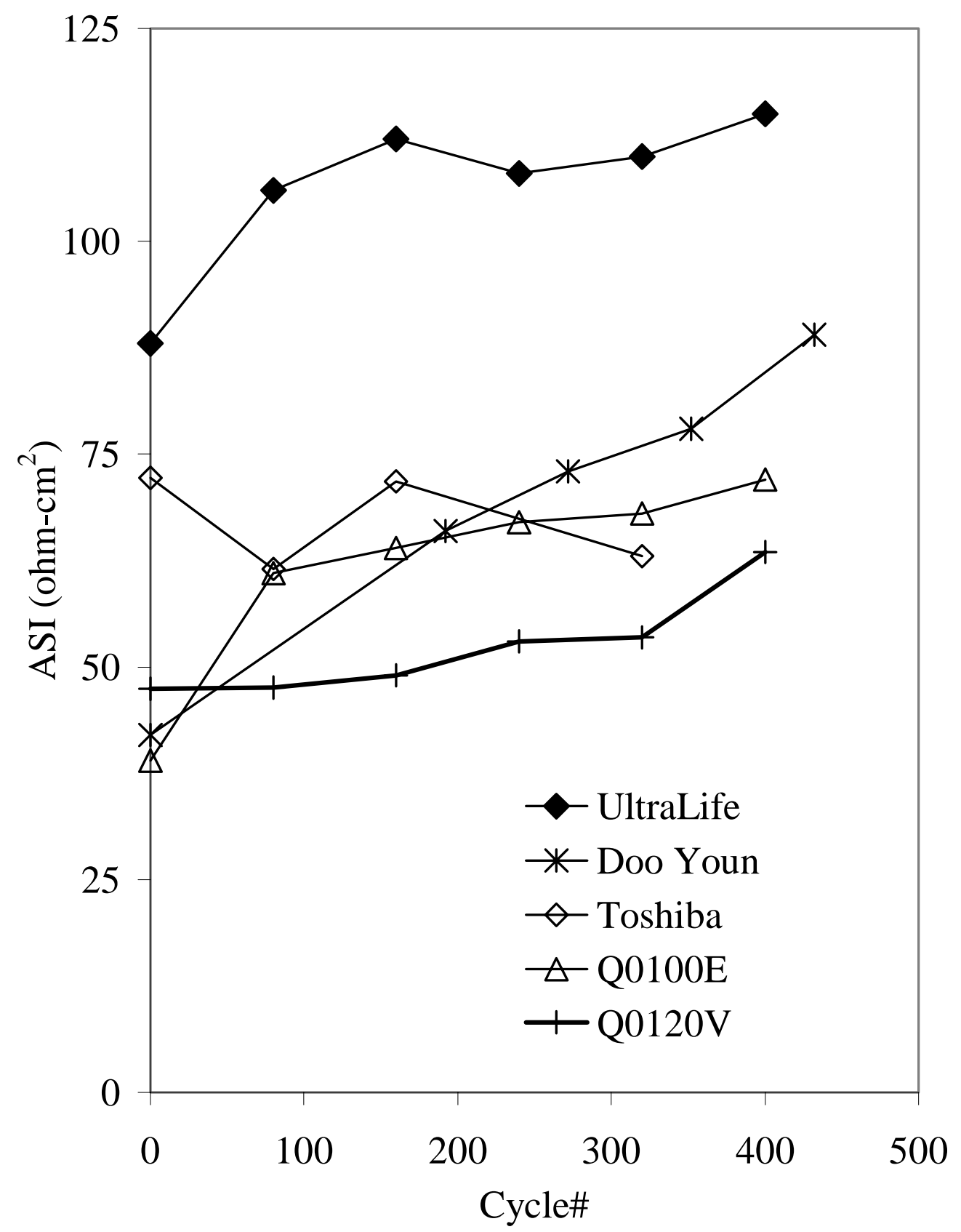

Figure 10. Total ASI Change with cycle-life testing of for five Li-ion cells, during $100 \%$ DOD Cycling $(\mathrm{C} / 2)$ at room temperature. 

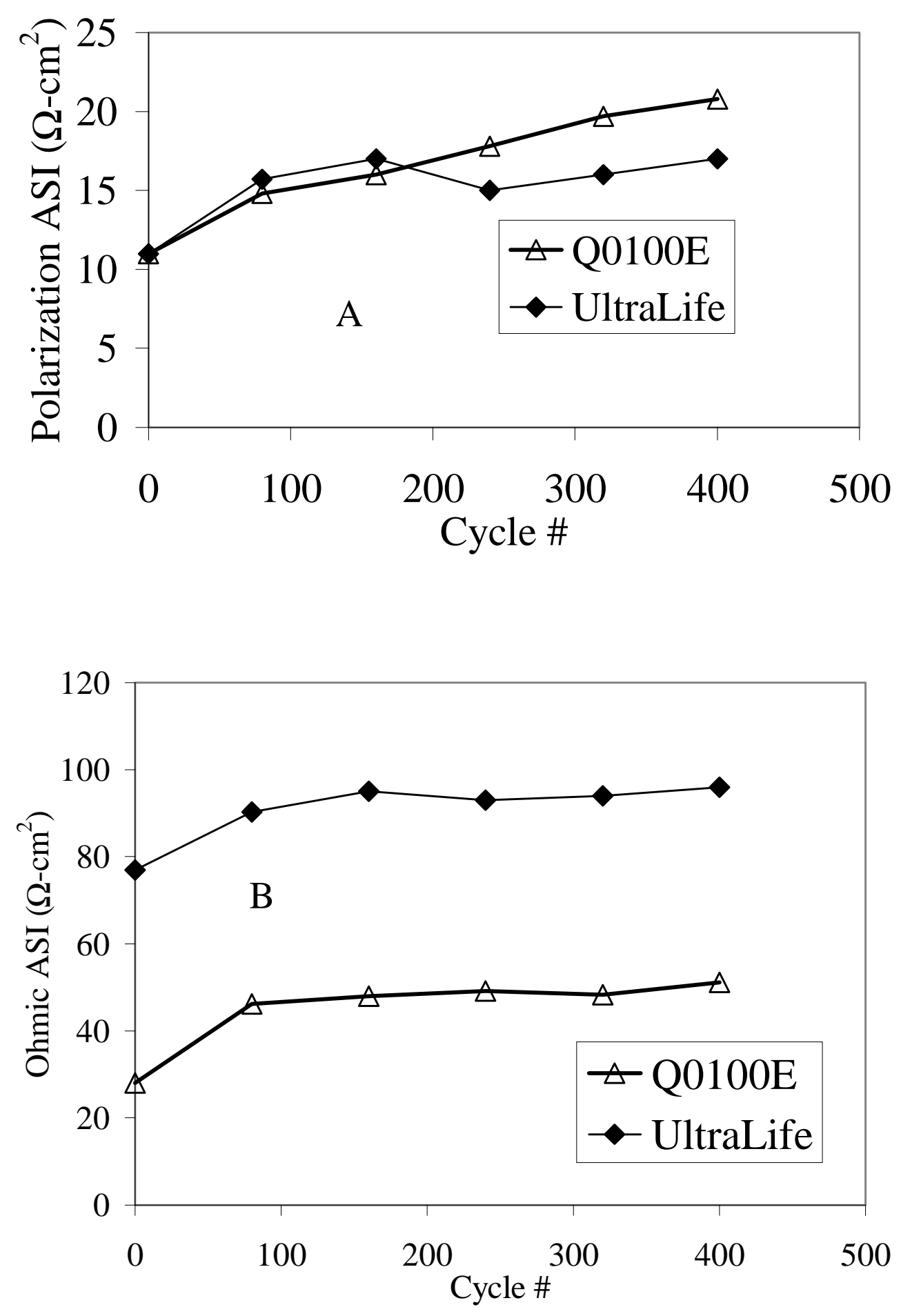

Figure 11. ASI changes with $100 \%$ DOD Cycling, for two $\mathrm{LiCoO}_{2}$ cells: the Quallion liquid electrolyte cell and the Ultralife gel polymer cells. Data shown as (A)ohmic and (B) polarization contributions. 

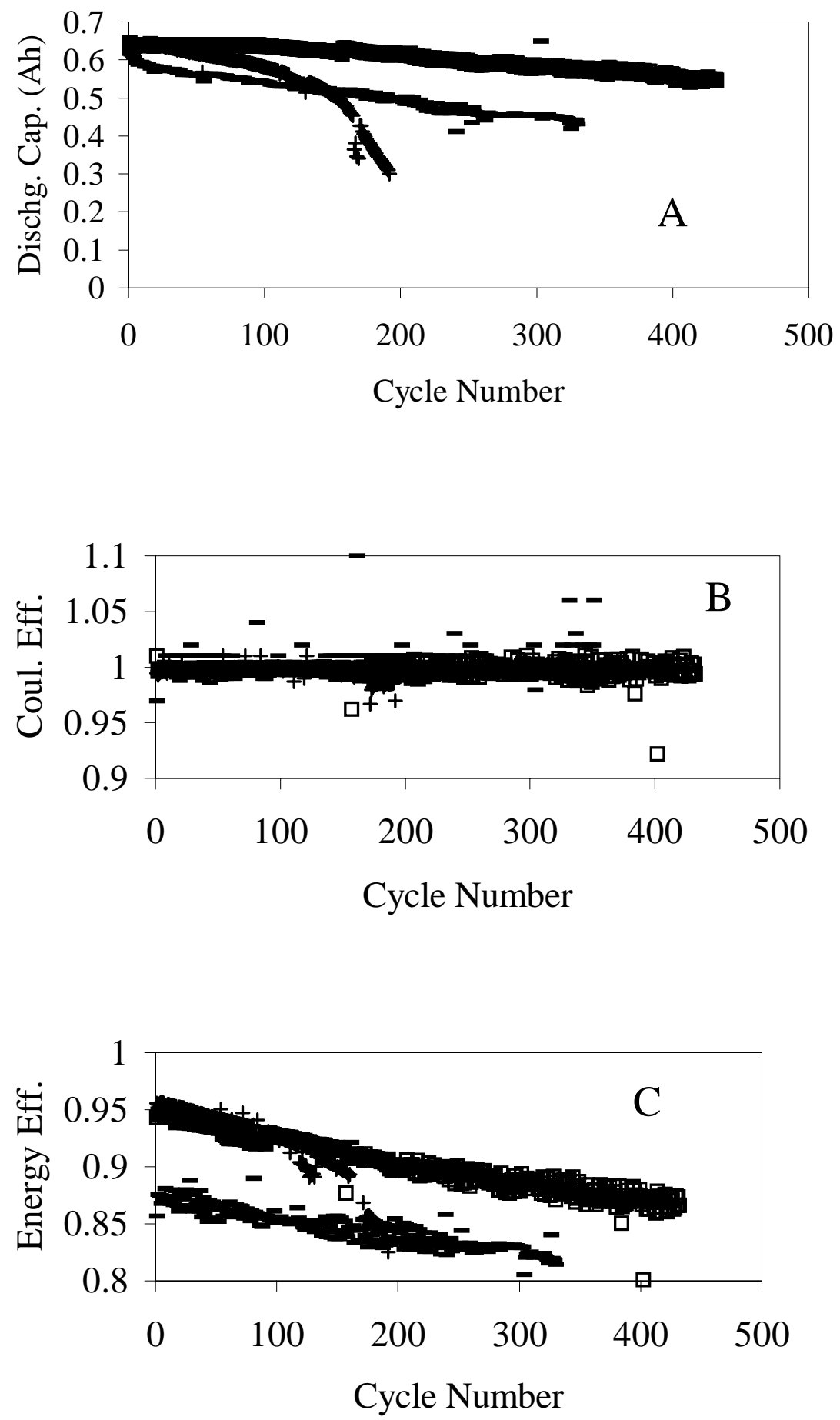

Figure 12. Performance data for Doo Youn cells AT 0, 25 AND 60C. (A) Discharge capacity, (B) coulombic efficiency, (C) energy efficiency. 


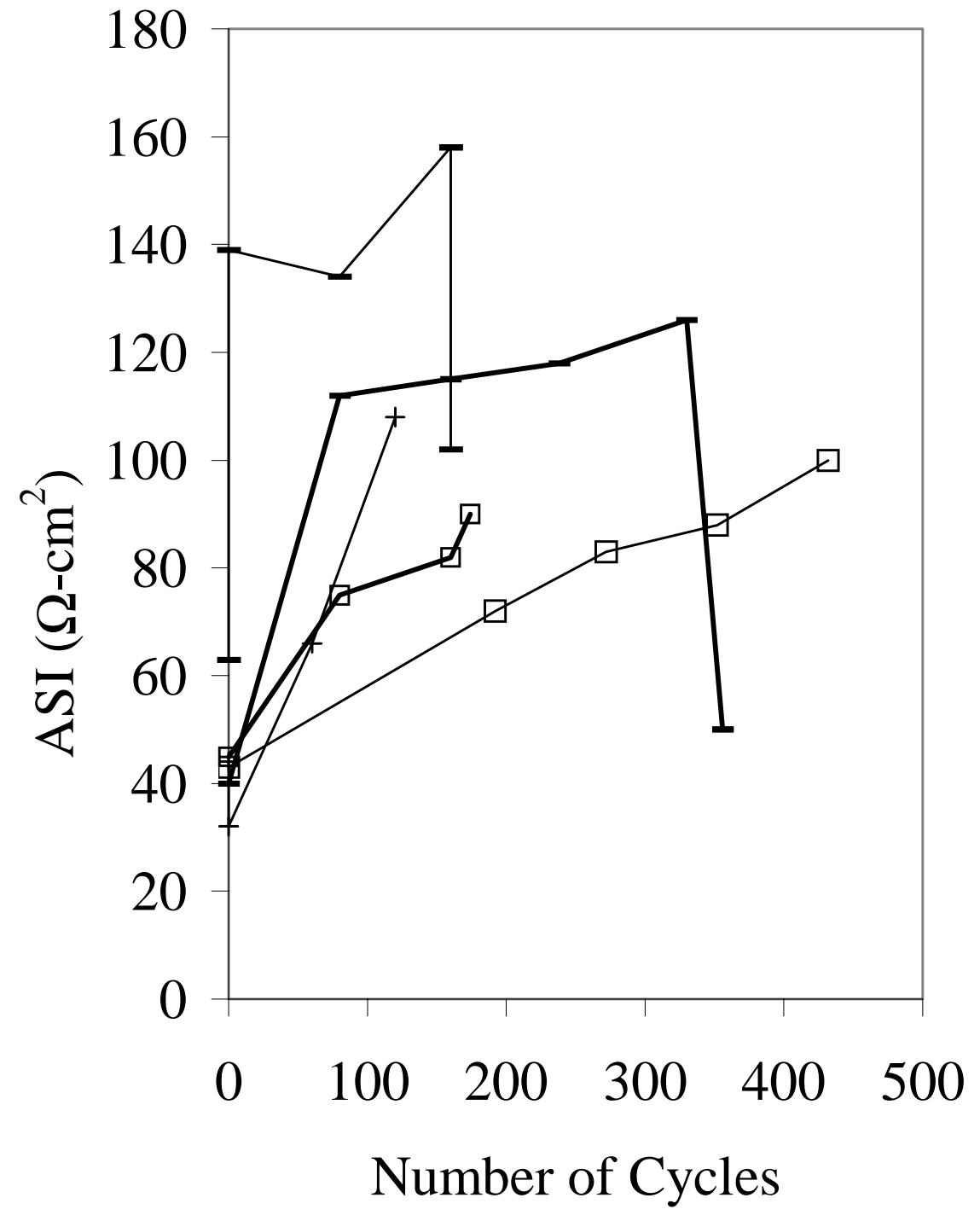

Figure 13. ASI changes in Doo Youn cells with $100 \%$ DOD $(\mathrm{C} / 2)$ cycling at three different temperatures 0,25 and $60^{\circ} \mathrm{C}$. 


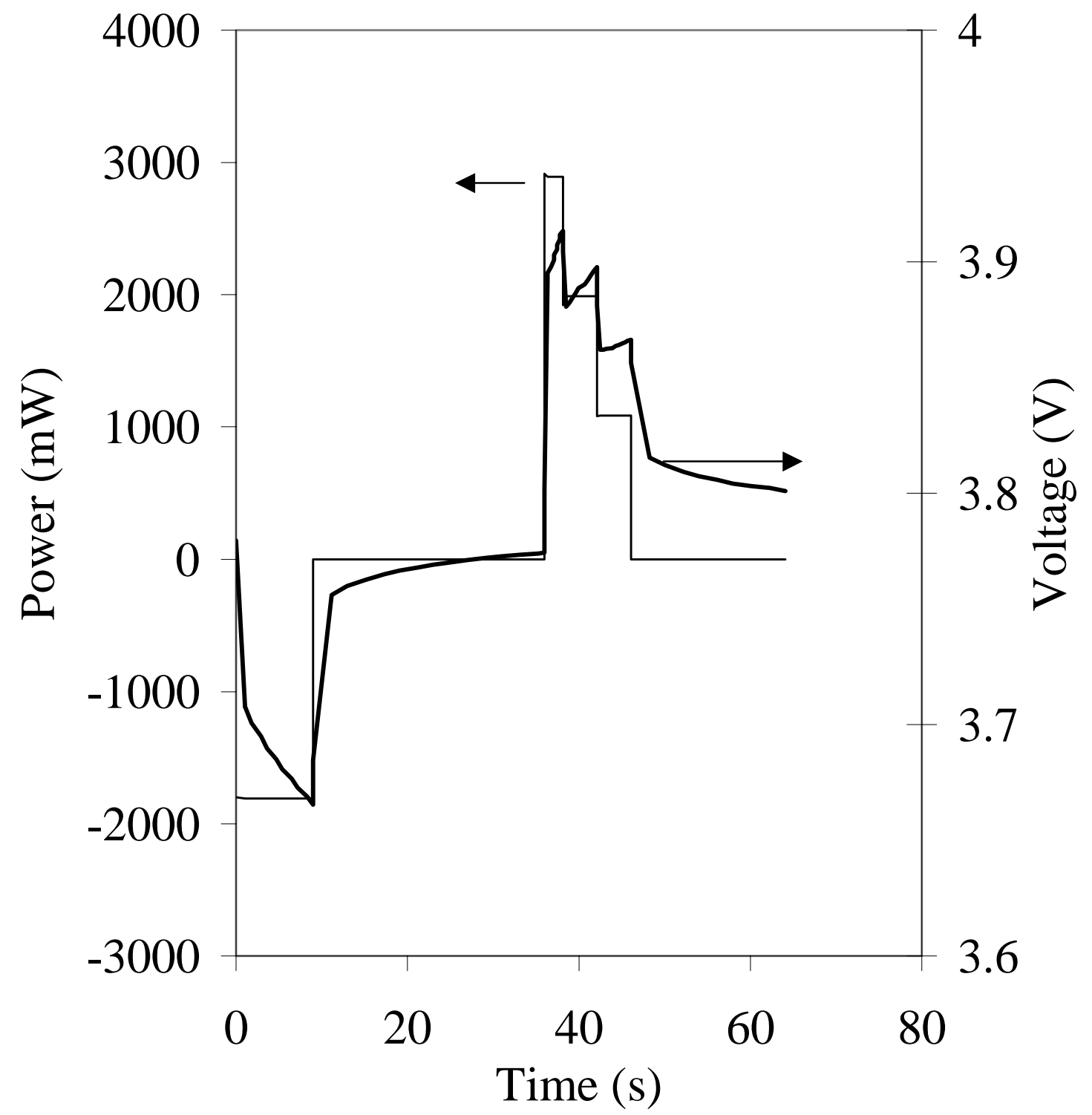

Fig. 14 Sample pulse series of the 25W Power Assist Life Cycle profile from PNGV. Power levels are scaled to the size of the battery. 

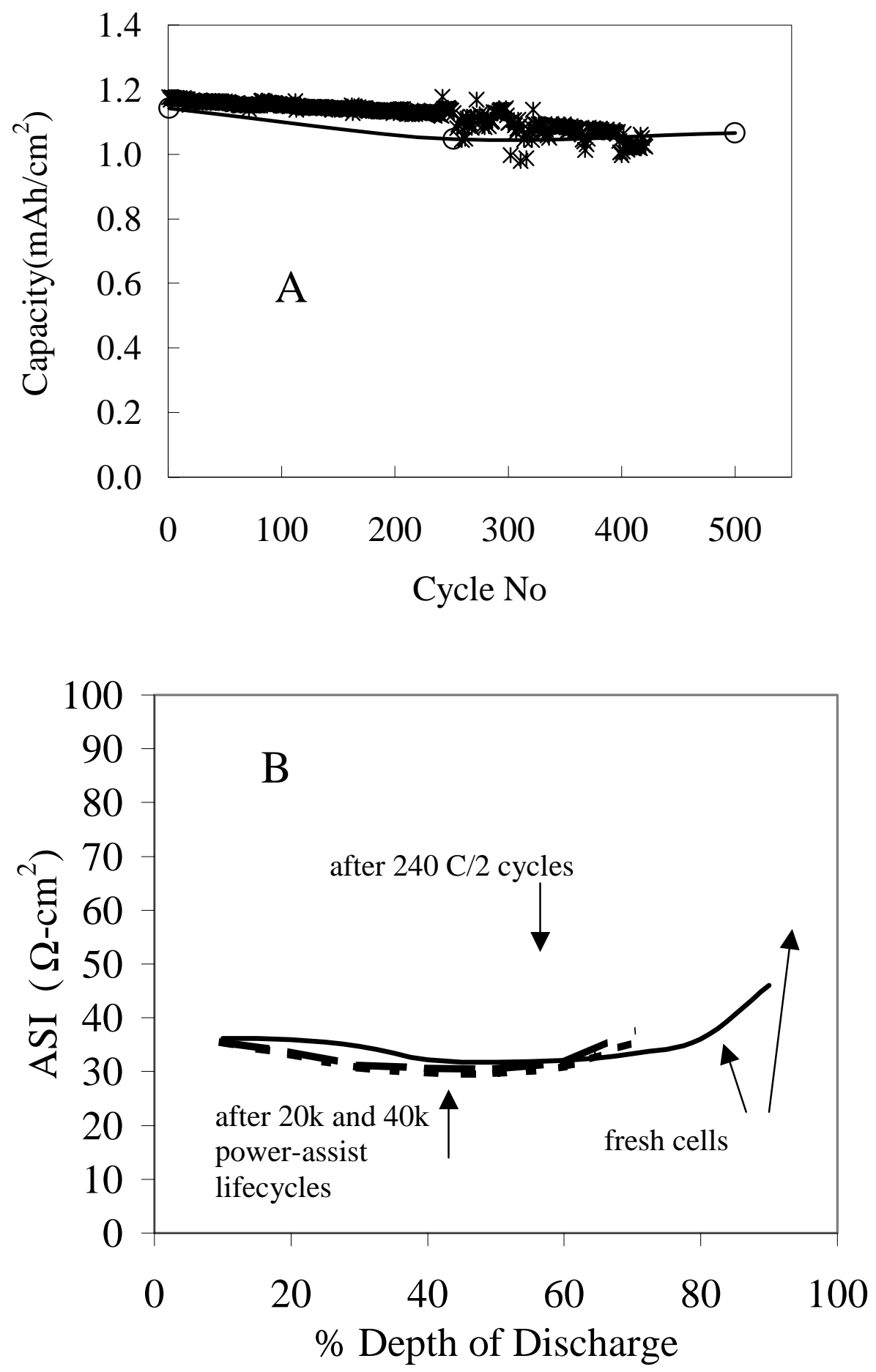

Fig.15 Performance of Q0120V cells during different types of cycling. A) Capacity fade ***** C/2 100\%DOD cycling, O Power-Assist Pulse Cycling; B) ASI changes during different cycling regimes. 

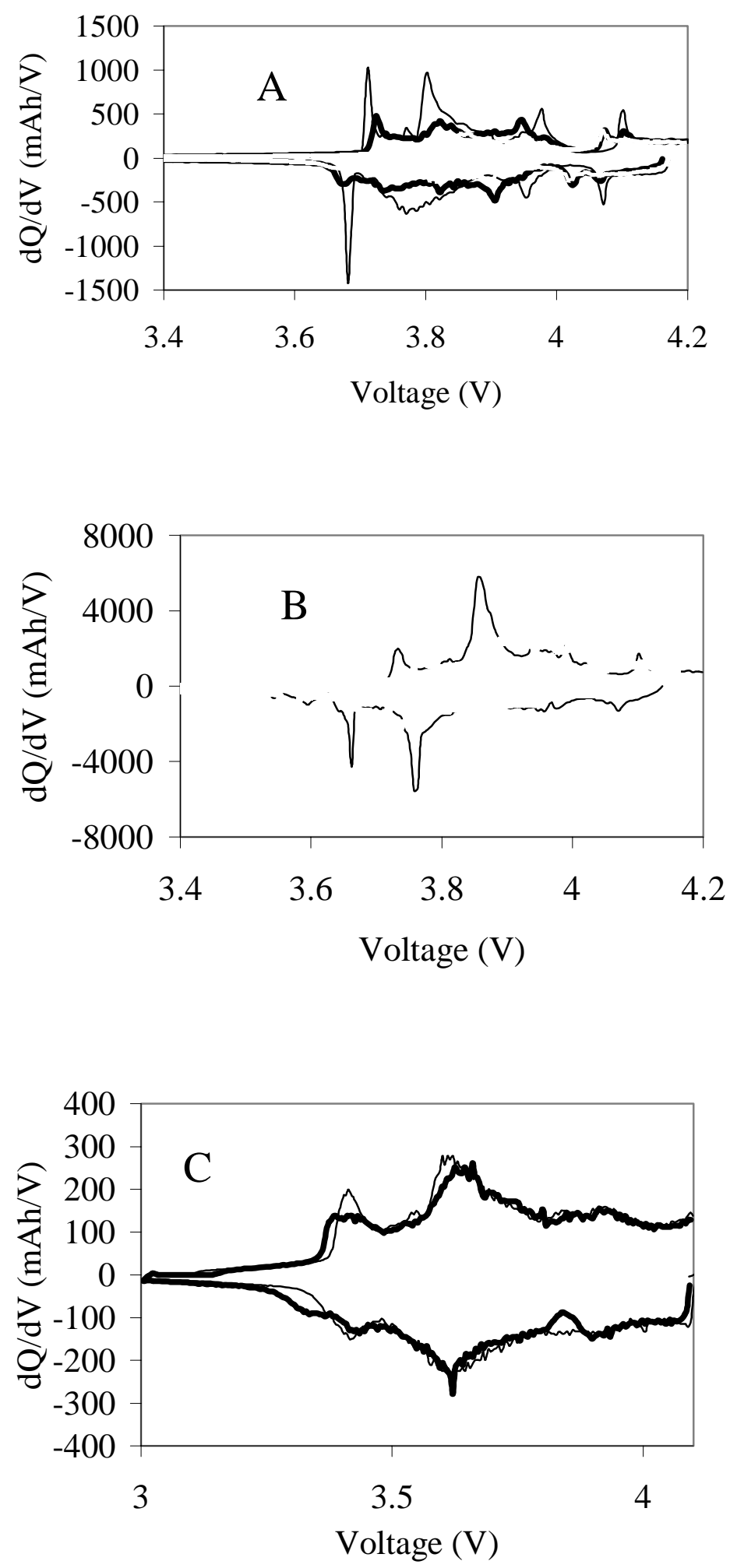

Figure 16. Low-rate $(\mathrm{C} / 25)$ tests during cell lifetime, shown as dQ/dV, A: Q0100E, B: UltraLife, and C: Q0120V, lines get darker with increased number of cycles.. 


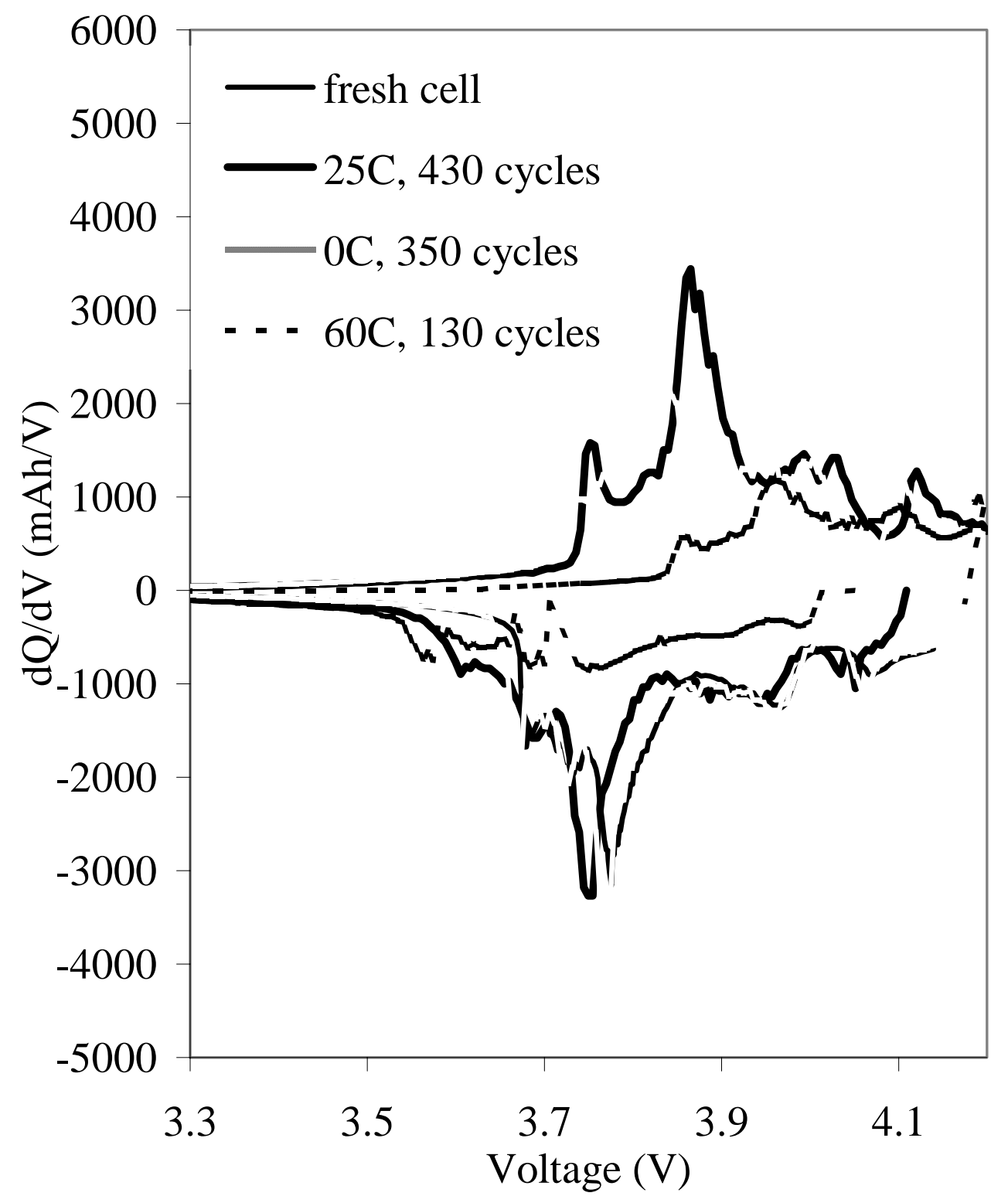

Figure 17. dQ/dV changes with cycling at different temperatures, Doo Youn cell fresh cell and cells cycled at 0,25 and $60^{\circ} \mathrm{C}$. 